\title{
Reduction in MnSOD promotes the migration and invasion of squamous carcinoma cells
}

\author{
JHEN-JIA FAN ${ }^{1,2^{*}}$, WEN-HSIEN HSU ${ }^{3 *}$, HAO-HSIANG HUNG ${ }^{1}$, WEI-JUN ZHANG ${ }^{1}$, YU-LIN A LEE ${ }^{4}$, \\ KU-CHUNG CHEN ${ }^{5}$, CHENG-YING $\mathrm{CHU}^{6}$, TZU-PING KO ${ }^{7}$, MING-TING LEE ${ }^{1,7}$, \\ CHENG-WEI LIN ${ }^{5}$ and CHIA-HSIUNG CHENG ${ }^{5}$
}

\author{
${ }^{1}$ Institute of Biochemical Sciences, National Taiwan University, Taipei $10617 ;{ }^{2}$ Food and Drug Administration, \\ Ministry of Health and Welfare, Taipei $11561 ;^{3}$ Department of Surgery, Wan-Fang Hospital, Taipei Medical University, \\ Taipei 11031, Taiwan, R.O.C.; ${ }^{4}$ Departments of Medicine and Pediatrics, Hospice and Palliative Medicine, \\ Duke University Hospital, Durham, NC 27710, USA; ${ }^{5}$ Department of Biochemistry and Molecular Cell Biology, \\ School of Medicine, College of Medicine; ${ }^{6}$ Center of Cancer Translational Medicine, Taipei Medical University, \\ Taipei 11031; ${ }^{7}$ Institute of Biological Chemistry, Academia Sinica, Taipei 11529, Taiwan, R.O.C.
}

Received November 23, 2018; Accepted March 6, 2019

DOI: $10.3892 /$ ijo.2019.4750

\begin{abstract}
Reactive oxygen species (ROS) homeostasis is maintained at a higher level in cancer cells, which promotes tumorigenesis. Oxidative stress induced by anticancer drugs may further increase ROS to promote apoptosis, but can also enhance the metastasis of cancer cells. The effects of ROS homeostasis on cancer cells remain to be fully elucidated. In the present study, the effect of a reduction in manganese superoxide dismutase (MnSOD) on the migration and invasion of A431 cells was investigated. Our previous micro-assay data revealed that the mRNA expression of MnSOD was higher in the invasive A431-III cell line compared with that in the parental A431 cell line (A431-P). In the present study, high protein levels of $\mathrm{MnSOD}$ and $\mathrm{H}_{2} \mathrm{O}_{2}$ production were observed in A431-III cells; however, catalase protein levels were significantly lower in A431-III cells compared with those in the A431-P cell line. The knockdown of MnSOD increased $\mathrm{H}_{2} \mathrm{O}_{2}$ levels, enzyme activity, the mRNA levels of matrix metalloproteinase-1, -2 and -9 , and the migratory and invasive abilities of the cells. Inducing a reduction in $\mathrm{H}_{2} \mathrm{O}_{2}$ using diphenyleneiodonium (DPI) and $\mathrm{N}$-acetyl-1-cysteine decreased the migratory abilities of the cell lines, and DPI attenuated the migratory ability that had been increased by MnSOD small interfering RNA knockdown.
\end{abstract}

Correspondence to: Professor Chia-Hsiung Cheng or Professor Cheng-Wei Lin, Department of Biochemistry and Molecular Cell Biology, School of Medicine, College of Medicine, Taipei Medical University, $250 \mathrm{Wu}-\mathrm{H}$ sing Street, Taipei 11031, Taiwan, R.O.C.

E-mail: chcheng@tmu.edu.tw

E-mail: cwlin@tmu.edu.tw

*Contributed equally

Key words: reactive oxygen species, hydrogen peroxide, manganese superoxide dismutase, metastasis, luteolin, quercetin
Luteolin $(\mathrm{Lu})$ and quercetin $(\mathrm{Qu})$ increased the expression of catalase and reduced $\mathrm{H}_{2} \mathrm{O}_{2}$ levels, but without an observed change in the protein levels of MnSOD. Taken together, these data suggest that reduced MnSOD may induce ROS imbalance in cells and promote the metastatic ability of cancer cells. $\mathrm{Lu}$ and Qu may attenuate these processes and may be promising potential anticancer agents.

\section{Introduction}

The overall redox environment in the cytosol and mitochondria is defined by the balance of reactive oxygen species (ROS). Elevated ROS production by mitochondria increases ROS-scavenging activity in order to maintain homeostasis (1). It is well established that high levels of ROS increase cellular oxidative stress, which leads to protein, lipid and DNA oxidation, and promotes tumor development. An increase in antioxidant ability sensitizes malignant cancer cells to chemotherapy. Therefore, the ROS balance in mitochondria serves an important role in tumor cells (2).

Manganese superoxide dismutase (MnSOD) regulates ROS homeostasis and exhibits tumor-suppressive and cancer-promoting functions (3). The expression of MnSOD has been reported to be reduced in cancer cells compared with that in normal tissues. The forced overexpression of MnSOD has resulted in delayed tumor growth in several cancer xenograft studies in mice $(4,5)$. A reduced expression of MnSOD has been reported in early tumor lesions, with the upregulation of MnSOD observed in metastatic tumor cells. In fibrosarcoma cells, the overexpression of MnSOD has been demonstrated to enhance metastatic capacity by modulating the expression of matrix metalloproteinase (MMP)-1 and other MMP family members (6); the pro-metastasis function of MnSOD was previously demonstrated to be hydrogen peroxide $\left(\mathrm{H}_{2} \mathrm{O}_{2}\right)$-dependent (7). In lung adenocarcinoma, MnSOD upregulates forkhead box protein M1/MMP-2 to promote tumor invasion (8). The expression of MnSOD has 
also been found to be upregulated in patients with primary gastric cancer and lymph node metastases (9). Additionally, the overall survival rate and pathologic tumor stages of patients with nasopharyngeal carcinoma was reported to be negatively correlated with the expression of MnSOD (10). The upregulation of MnSOD in cancer cells may increase the production of $\mathrm{H}_{2} \mathrm{O}_{2}$ to promote tumor growth in later stages of prostate, colon and lung cancer. ROS homeostasis is altered by the superoxide $/ \mathrm{H}_{2} \mathrm{O}_{2}$ ratio, which can promote the proliferation and metastasis of cancer cells (11), and the scavenging of mitochondria superoxide may reduce the metastatic ability of cancer cells $(12,13)$.

Flavonoids are plant phenolic compounds with antioxidant and chelating activities (14-18). Numerous studies have indicated that two dietary flavonoid constituents, luteolin $(\mathrm{Lu})$, a flavone, and quercetin $(\mathrm{Qu})$, a flavonol, generally appear to be the most potent among plant flavonoids in terms of their in vitro biological activities (19-21). These flavonoids exhibit a variety of anticancer effects, including inhibition of cell growth and kinase activity, induction of apoptosis, stimulation of differentiation, suppression of MMP secretion, tumor cell adhesion, invasive behavior, metastasis and angiogenesis $(21,22)$. Lu has been reported as a potent anticancer agent in squamous cell carcinoma cells and other cancer cell lines (23-26). Lu has also been reported to alter the activity of antioxidant enzymes in cancer cells. In $\mathrm{CH} 27$ cells, $\mathrm{Lu}$ induced apoptosis and increased the activation and expression of copper-dependent superoxide dismutase (CuSOD) and catalase (27), and has been observed to decrease the cisplatin-induced renal production of ROS by increasing the expression of CuSOD and catalase (28). $\mathrm{Qu}$ has also been reported to induce catalase activity in studies investigating ROS; catalase activity was reduced in a 3-nitropropionic acid-induced mice model of Huntington's disease, whereas treatment with $\mathrm{Qu}$ reversed the reduced catalase activity in the model (29). In a toxicology study, the co-administration of Qu with chromium led to significantly enhanced expression of catalase in mice compared with that in mice administered with chromium alone (30).

Our previous study established the invasive A431-III cell line from the parental A431 (A431-P) cell line (31). The invasive A431-III cells expressed higher levels of MMP-2 and -9 compared with levels in the A431-P cell line, and exhibited high metastatic ability mediated via epithelial-mesenchymal transition (EMT) signaling coordinated by Snail (32). Additionally, our previous study indicated that transglutaminase 2 contributes to the metastasis of A431-III cells by activating phosphatidylinositol-3-kinase (PI3K) and nuclear factor- $\mathrm{\kappa B}$ signaling, which induces the expression of Snail and MMP-9 (33). The flavonoids Lu and Qu have been shown to inhibit EMT signaling in squamous cell carcinoma cells (34). Additionally, protein kinase B (Akt)/mammalian target of rapamycin (mTOR)/c-Myc signaling induced the expression of 40S ribosomal protein S (RPS)12 and RPS19 in A431-III cells and promoted metastasis, which was attenuated by $\mathrm{Lu}$ and $\mathrm{Qu}(35,36)$. Furthermore, $\mathrm{Lu}$ and $\mathrm{Qu}$ reduced the expression of UBE2S to attenuate the activation of hypoxic and EMT signaling in cancer cells (37). Taken together, these previous findings suggest that $\mathrm{Lu}$ and $\mathrm{Qu}$ may be promising candidates as anticancer agents (18).
The present study aimed to investigate the effects of an ROS imbalance, via the knockdown of MnSOD and the use of antioxidant reagents, on the migratory and invasive abilities of A431-P and A431-III cancer cells. The effects of $\mathrm{Lu}$ and $\mathrm{Qu}$ on the production of $\mathrm{H}_{2} \mathrm{O}_{2}$ and expression of oxidative enzymes were also analyzed.

\section{Materials and methods}

Materials. A431-P (A431) cells were obtained from the American Type Culture Collection (Manassas, VA, USA). A431-III cells were generated in our laboratory (Ming-Ting Lee, Institute of Biological Chemistry, Academia Sinica, Taipei, Taiwan) from the parental A431-P tumor cells (31). RPMI-1640 and fetal bovine serum (FBS) were obtained from Gibco; Thermo Fisher Scientific, Inc. (Waltham, MA, USA). Anti-MnSOD and anti- $\beta$-actin antibodies were purchased from Santa Cruz Biotechnology, Inc. (Dallas, TX, USA). Anti-Cu/zinc (Zn)SOD antibody was obtained from Merck KGaA (Darmstadt, Germany). Anti-catalase antibody was obtained from Chemicon International (Thermo Fisher Scientific, Inc.). Polymerase chain reaction (PCR) forward and reverse primers were purchased from Purigo Biotech (Taipei, Taiwan). Luteolin (purity $\geq 95 \%$ ) was purchased from Toronto Research Chemicals, Inc. (North York, ON, Canada). Quercetin (purity $\geq 95 \%$ ) was purchased from Nacalai Tesque (Kyoto, Japan). Agarose and dimethyl sulfoxide (DMSO) were purchased from Merck KGaA. Epidermal growth factor was obtained from Upstate Biotechnology, Inc. (Lake Placid, NY, USA) and dissolved in RPMI-1640 medium. Unless otherwise indicated, all other reagents were obtained from Merck KGaA. $\mathrm{Lu}$ and $\mathrm{Qu}$ were dissolved in 100\% DMSO, and their concentrations were adjusted to obtain $100 \mathrm{mM}$ stock solutions.

Cell culture. The A431-P and A431-III cells were cultured as described in our previous report (31). The A431-P and A431-III cells were incubated in a $5 \% \mathrm{CO}_{2}$ air atmosphere at $37^{\circ} \mathrm{C}$ with RPMI-1640 medium containing 10\% FBS (both from Gibco; Thermo Fisher Scientific, Inc.).

Preparation of cell lysates. All procedures for preparing cell lysates were performed on ice. The A431-P and A43-1III sub-lines were harvested and washed three times with cold phosphate-buffered saline (PBS; Bioman, Taipei, Taiwan) and then were lysed in gold lysis buffer [20 mM Tris- $\mathrm{HCl},(\mathrm{pH} 7.9)$, $1 \mathrm{mM}$ EGTA, $0.8 \% \mathrm{NaCl}, 0.1 \mathrm{mM}, \beta$-glycerylphosphate, $1 \mathrm{mM}$ sodium pyrophosphate, $10 \mathrm{mM} \mathrm{NaF}, 1 \mathrm{mM} \mathrm{Na}_{4} \mathrm{P}_{2} \mathrm{O}_{7}$, $1 \mathrm{mM} \mathrm{Na}_{3} \mathrm{VO}_{4}, 10 \%$ glycerol and $1 \%$ Triton X-100] containing $1 \mathrm{mM}$ phenylmethylsulfonyl fluoride, $10 \mu \mathrm{g} / \mathrm{ml}$ aprotinin and $10 \mu \mathrm{g} / \mathrm{ml}$ leupeptin.

Transfection of small interfering RNA (siRNA). MnSOD siRNA and non-specific RNA (both from Ambion; Thermo Fisher Scientific, Inc.) were dissolved in nuclease-free water to a concentration of $10 \mu \mathrm{M}$. The A431-P and A431-III cells $\left(5 \times 10^{5}\right)$ were plated onto 6 -well plates and allowed to adhere overnight. $2 \mu$ l Lipofectamine ${ }^{\circledR} 2000$ (Thermo Fisher Scientific, Inc.; $2 \mu \mathrm{l}$ per well) was added into $100 \mu \mathrm{l}$ serum-free RPMI-1640, thoroughly mixed and incubated at room temperature for $5 \mathrm{~min}$. MnSOD siRNA (4 $\mu \mathrm{l}$ per well) was 
added into $100 \mu \mathrm{l}$ of serum-free RPMI-1640, thoroughly mixed and then combined with the diluted Lipofectamine 2000. The siRNA/Lipofectamine ${ }^{\circledR}$ mixture was gently mixed and incubated at room temperature for $30 \mathrm{~min}$, and then added into the 6-well plate containing cells in $2 \mathrm{ml}$ serum-free RPMI-1640 for $24 \mathrm{~h}$. All subsequent assays were performed at $24 \mathrm{~h}$ post-transfection.

Wound-healing assay. The A431-P $\left(1 \times 10^{6}\right.$ cells/well) and A431-III cells ( $1 \times 10^{6}$ cells/well) were seeded into 6-well plates and incubated overnight. Manual scratching using a pipette tip and subsequent washing with PBS was performed to create the wound in the cell monolayers. The A431-P cells were treated with 10,30 and $50 \mu \mathrm{M}$ of $\mathrm{H}_{2} \mathrm{O}_{2}$, and the A431-III cells were treated with $1.5,2.5$ and $5 \mu \mathrm{M}$ of $\mathrm{N}$-acetyl-1-cysteine (NAC; Sigma-Aldrich; Merck KGaA) at $37^{\circ} \mathrm{C}$ for $16-\mathrm{h}$. Additionally, A431-P and A431-III cells transfected with MnSOD siRNA was pre-treated with $20 \mu \mathrm{M}$ of diphenyleneiodonnium (DPI; Sigma-Aldrich; Merck $\mathrm{KGaA}$ ) at $37^{\circ} \mathrm{C}$ for 3 -h and then cultured for an additional $17 \mathrm{~h}$ at $37^{\circ} \mathrm{C}$ were also analyzed. Images of the monolayers were captured following wounding using phase-contrast microscopy and an Olympus IX70 camera (Olympus Corporation, Tokyo, Japan) to determine the size of the wound.

Migration assay. Transwell chambers with polycarbonate filters were coated with extracellular matrix (both from BD Biosciences, Franklin Lakes, NJ, USA) for $1 \mathrm{~h}$ at $25^{\circ} \mathrm{C}$. Culture medium was added to the lower compartment of the chamber. The upper chambers were loaded with $10^{5}$ cells/well in serum-free medium and the lower chambers were filled with medium containing $10 \% \mathrm{FBS}$ as a chemoattractant for the cells. The cells were incubated at $37^{\circ} \mathrm{C}$ in a humidified atmosphere (95\% air and $5 \% \mathrm{CO}_{2}$ ) for $10 \mathrm{~h}$. Following incubation, the invading cells were fixed with $1 \%$ glutaraldehyde/PBS for $15 \mathrm{~min}$ at $25^{\circ} \mathrm{C}$, and then stained with crystal violet for $30 \mathrm{~min}$. Cells on the upper layer of the filter were removed, and images were captured using an Olympus SZ-PT (Olympus Corporation) microscope and counted. Data of the migrated cell numbers represent the average of three typical fields per sample.

Invasion assay. Chambers (Corning, Inc., Corning, NY, USA) with an $8-\mu \mathrm{m}$ pore size were pre-coated with $20 \mu \mathrm{g} / 100 \mu \mathrm{l} \mathrm{EHS}$ Matrigel(BD Biosciences). Following drying, the chambers were rinsed with $100 \mu \mathrm{l}$ serum-free RPMI medium for rehydration. The cells $\left(10^{5}\right.$ cells/well $)$ in serum-free medium were loaded into the chamber and inserted into a 24-well plate (Corning, Inc.). A $0.5-\mathrm{ml}$ aliquot of medium supplemented with $10 \% \mathrm{FBS}$ was added to the lower wells to serve as a chemoattractant for the cells. The Matrigel invasion chambers were incubated at $37^{\circ} \mathrm{C}$ for $60 \mathrm{~h}$ in $0.5 \% \mathrm{CO}_{2}$. Following incubation, the invading cells were fixed with $1 \%$ glutaraldehyde/PBS for $15 \mathrm{~min}$ and then stained with crystal violet for $30 \mathrm{~min}$. Images of the cells on the upper layer of the chamber were captured with an Olympus SZ-PT microscope and counted.

Crystal violet staining. Following removal of the cell culture medium, the cells were washed twice with PBS and then fixed using $1 \%$ glutaraldehyde for $15 \mathrm{~min}$. The glutaraldehyde was removed, and the cells were washed twice with PBS, following which crystal violet (Koch-Light Research Laboratories, Ltd., Gauteng, South Africa) stain was added for $30 \mathrm{~min}$. The cells were then washed twice with distilled water. The optical density of the stained cells was measured at $595 \mathrm{~nm}$.

Western blot analysis. The protein concentration was determined by Bio-Rad Protein Assay kit (Bio-Rad, Hercules, CA, USA). The $20 \mu \mathrm{g}$ of total protein was used to analyzed and separated by $10 \%$ SDS PAGE, and then transferred onto a nitrocellulose membrane (Pall Life Sciences, Port Washington, NY, USA). The nitrocellulose membrane was blocked with $3 \%$ bovine serum albumin at room temperature for $1 \mathrm{~h}$ and then incubated with the anti-CuSOD (1:5,000; cat. no. MABC684; Merck KGaA), anti-MnSOD (1:5,000; cat. no. sc-137254; Santa Cruz Biotechnology, Inc.), anti-catalase (1:1,000; cat. no. AML0010; Thermo Fisher Scientific, Inc.) and anti- $\beta$-actin (1:5,000; cat. no. sc-47778; Santa Cruz Biotechnology, Inc.) antibodies in blocking solution at $4^{\circ} \mathrm{C}$ overnight. The membranes were thoroughly washed four times with TBST [20 mM Tris- $\mathrm{HCl}$ (pH 7.6), 0.8\% NaCl, and 0.25\% Tween-20] and twice with Tris-buffered saline, and were then incubated with horseradish peroxidase-conjugated secondary antibody (1:5,000; cat. no. 715-035-150; Jackson ImmunoResearch Laboratories, Inc., West Grove, PA, USA) in TBST for $1 \mathrm{~h}$ at room temperature. Following four washes with TBST, the blots were stained using the chemiluminescent SuperSignal substrate (Thermo Fisher Scientific, Inc.) and immunoreactive signals were visualized by exposure to X-ray film.

SOD activity gel assay. SOD activity was measured using the modified nitroblue tetrazolium (NBT) method (38). The $20 \mu \mathrm{g}$ of total protein from each sample were separated using a native $10 \%$ polyacrylamide gel. Following three washes with $2 \%$ Triton X-100 and distilled water, the gel was incubated with $2.43 \mathrm{mM}$ NBT (Sigma-Aldrich; Merck KGaA) in the dark for $20 \mathrm{~min}$ at at $25^{\circ} \mathrm{C}$, then $28 \mu \mathrm{M}$ riboflavin and $28 \mathrm{mM}$ TEMED (Sigma-Aldrich; Merck KGaA) were added to react for $15 \mathrm{~min}$ in the dark at $25^{\circ} \mathrm{C}$. Following exposure of the gel to light, the achromatic bands corresponding to SOD activity appeared on a dark-purple background.

Gelatin zymography. The activity of secreted MMP was analyzed by casein and gelatin zymography (39). The A431-P and A431-III sub-lines (5X10 5 cells/well) were seeded into 6-well plates and then cultured in $1.5 \mathrm{ml}$ of serum-free medium for $24 \mathrm{~h}$. The conditioned medium was collected and separated on a gradient polyacrylamide gel that contained gelatin or casein as a substrate. The gel was incubated with substrate buffer [50 mM Tris- $\mathrm{HCl}(\mathrm{pH} 8.0), 5 \mathrm{mM} \mathrm{CaCl}_{2}$ and $0.02 \% \mathrm{NaN}_{3}$ ] at $37^{\circ} \mathrm{C}$ for 48 or $96 \mathrm{~h}$ prior to staining with Coomassie blue ( $0.25 \%$ R250, 50\% ethanol and $10 \%$ acetic acid). The gel was destained with destaining buffer $(20 \%$ ethanol and $10 \%$ acetic acid) until the achromatic bands appeared on a blue background.

ROS measurement. The production of $\mathrm{H}_{2} \mathrm{O}_{2}$ was measured using an Amplex ${ }^{\circledR}$ Red Hydrogen Peroxide/Peroxidase Assay kit (Thermo Fisher Scientific, Inc.) following the manufacturer's protocol. Briefly, the A431-P and A431-III sub-lines 


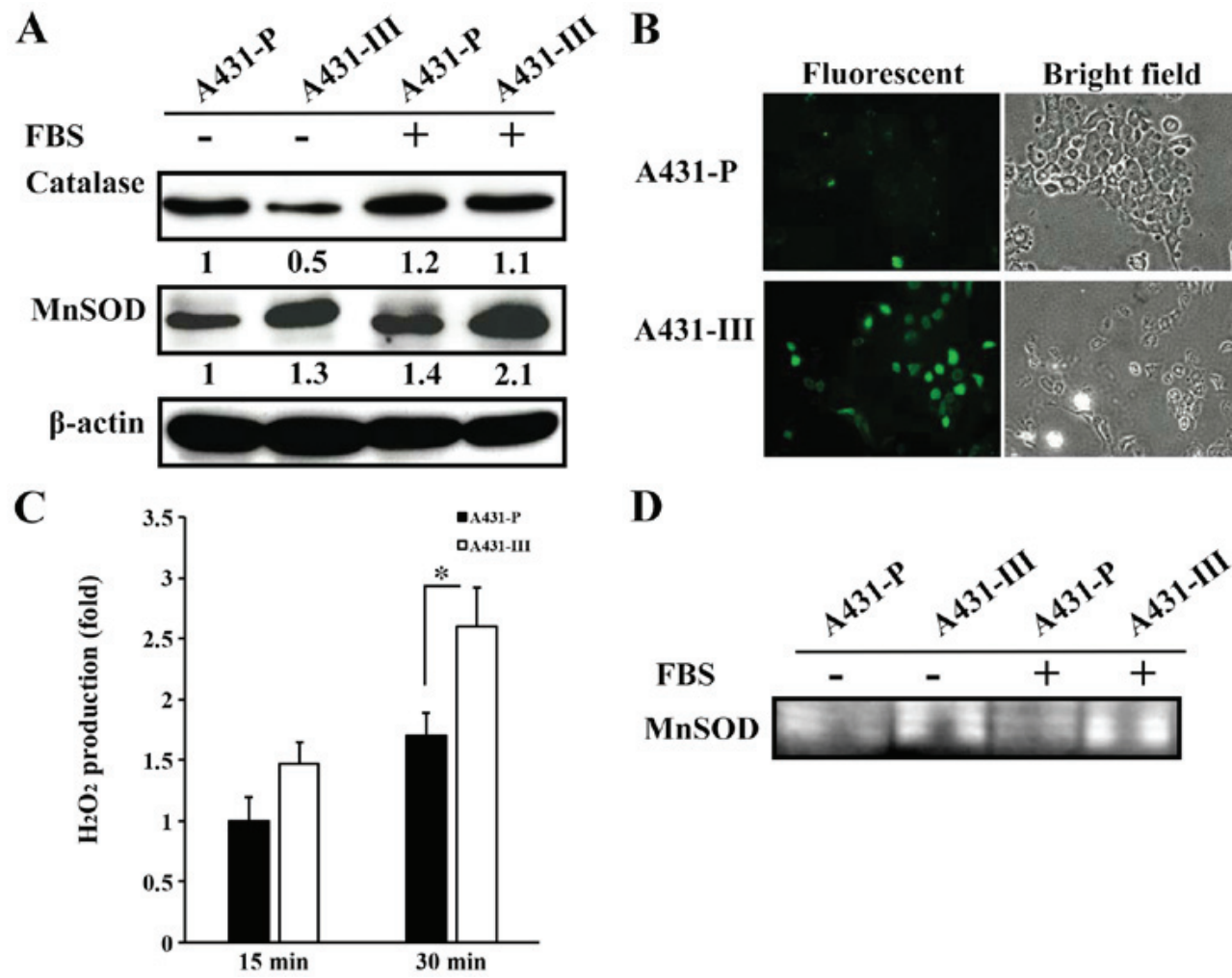

Figure 1. $\mathrm{H}_{2} \mathrm{O}_{2}$ production is regulated by MnSOD and catalase in A431-P and A431-III cells. (A) Protein levels of MnSOD and catalase in A431-P and A431-III cells cultured with or without FBS were determined by western blot analysis. (B) Production of $\mathrm{H}_{2} \mathrm{O}_{2}$ in A431-P and A431-III cells was analyzed using 2',7'-dichlorofluorescin diacetate incubation followed by fluorescent microscopy (magnification, $\mathrm{x} 200$ ) and (C) detection of the fluorescent intensity using the Amplex ${ }^{\circledR}$ Red Hydrogen Peroxide/Peroxidase Assay kit. Statistical significance was determined by a one-way ANOVA with Tukey's test ("P<0.05). (D) Enzyme activity of MnSOD was analyzed using the nitroblue tetrazolium method. $\mathrm{H}_{2} \mathrm{O}_{2}$, hydrogen peroxide; MnSOD, manganese superoxide dismutase; FBS, fetal bovine serum.

$\left(1 \times 10^{4}\right.$ cells/well) were seeded into a 96-well plate (Corning, Inc.) and incubated overnight. The A431-III cells were treated with $20 \mu \mathrm{M}$ of $\mathrm{Lu}$ and $\mathrm{Qu}$ at $37^{\circ} \mathrm{C}$ for $24-\mathrm{h}$, following which the cells were analyzed using Amplex Red reagent (Thermo Fisher Scientific, Inc.) and a SPARK ${ }^{\circledR}$ plate reader (Tecan Group, Inc., Mannedorf, Switzerland) to measure the absorbance. For fluorescent microscopy, 2',7'-dichlorofluorescin diacetate (2',7'-DCF-DA; Thermo Fisher Scientific, Inc.) was used as the probe to detect ROS, followed by observation under an Olympus IX70 (Olympus Corporation) microscope.

Reverse transcription-polymerase chain reaction (RT-PCR) messenger $(m) R N A$ analysis. The cells were cultured in $10-\mathrm{cm}$ dishes to $90 \%$ confluence, detached using $0.25 \%$ trypsin for $10 \mathrm{~min}$ and then blocked in medium containing 10\% FBS medium. Total RNA was extracted by using an RNeasy Mini kit (Qiagen, Inc., Valencia, CA, USA) according to the manufacturer's protocol. The SuperScript III First-Strand Synthesis system (Thermo Fisher Scientific, Inc.) was used for first-strand cDNA synthesis according to the manufacturer's protocol. For PCR amplification, primers were designed according to DNA sequences as follows: MMP-1, forward, 5'-GGA GGA AAT CTT GCT CAT-3' and reverse, 5'-CTC AGA AAG AGC AGC ATC-3'; MMP-3, forward, 5'-ATT ATA CAC CAG ATT TGC CAA AAG A-3' and reverse, 5'-AAA AGA ACC CAA ATT CTT CAA AAA C-3'; MMP-9, forward, 5'-CCG CGA CAC CAA ACT GGA T-3' and reverse, 5'-TGT ACC GCT ATG GTT ACA C-3'; and $\beta$-actin, forward, 5'-GCT CGT CGT CGA CAA CGG CTC-3' and reverse, 5'-CAA ACA TGA TCT GGG TCA
TCT TCTC-3'. Amplification of $\beta$-actin cDNA was used as the control reference gene. The following profile was used for PCR amplification of $500 \mathrm{ng}$ of cDNA by KAPA HiFi PCR Kits (Kapa Biosystems, Woburn, MA, USA) in a GeneAmp PCR System 9700 (Thermo Fisher Scientific, Inc.): an initial denaturation step at $96^{\circ} \mathrm{C}$ for $5 \mathrm{~min}$, followed by 30 cycles of $96^{\circ} \mathrm{C}$ for $30 \mathrm{sec}, 55^{\circ} \mathrm{C}$ for $30 \mathrm{sec}$, and $72^{\circ} \mathrm{C}$ for $30 \mathrm{sec}$, with a final extension at $72^{\circ} \mathrm{C}$ for $10 \mathrm{~min}$.

Statistical analysis. Data from three independent experiments are expressed as the mean \pm standard deviation. For comparisons between two groups, statistical analysis was determined using Student's unpaired t-test (SPSS Statistics ver. 24; IBM, Chicago, IL, USA). For comparison of more than two groups, one-way analysis of variance followed by Tukey's test was used (SPSS Statistics ver. 24 ; IBM). $\mathrm{P}<0.05$ was considered to indicate a statistically significant difference.

\section{Results}

Levels of MnSOD, catalase, and $\mathrm{H}_{2} \mathrm{O}_{2}$ in the A431-III sub-line. Our previous studies identified the mechanism of metastatic activation in an A431-III cell model (32-36). ROS signaling is reported to activate metastasis in cancer cells $(2,40)$. To analyze the role of MnSOD in the metastasis of cancer cells, the expression levels of MnSOD and catalase were compared in A431-III and A431-P cells. The protein levels of MnSOD were higher in the A431-III cells than in the A431-P cells cultured with or without FBS; however, 


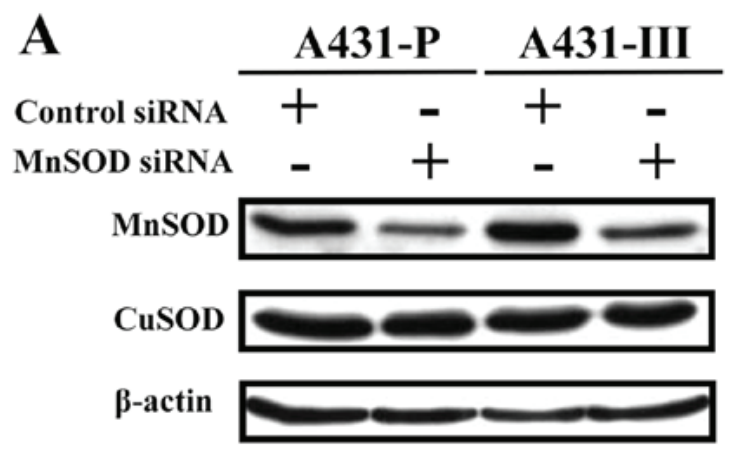

B

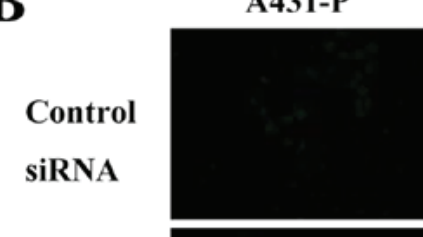

MnSOD

SiRNA

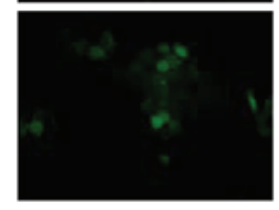

A431-III
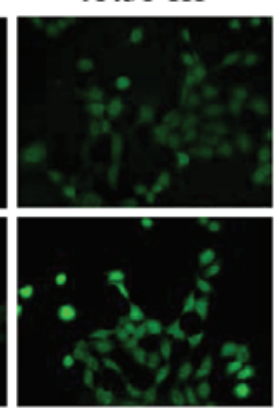

D
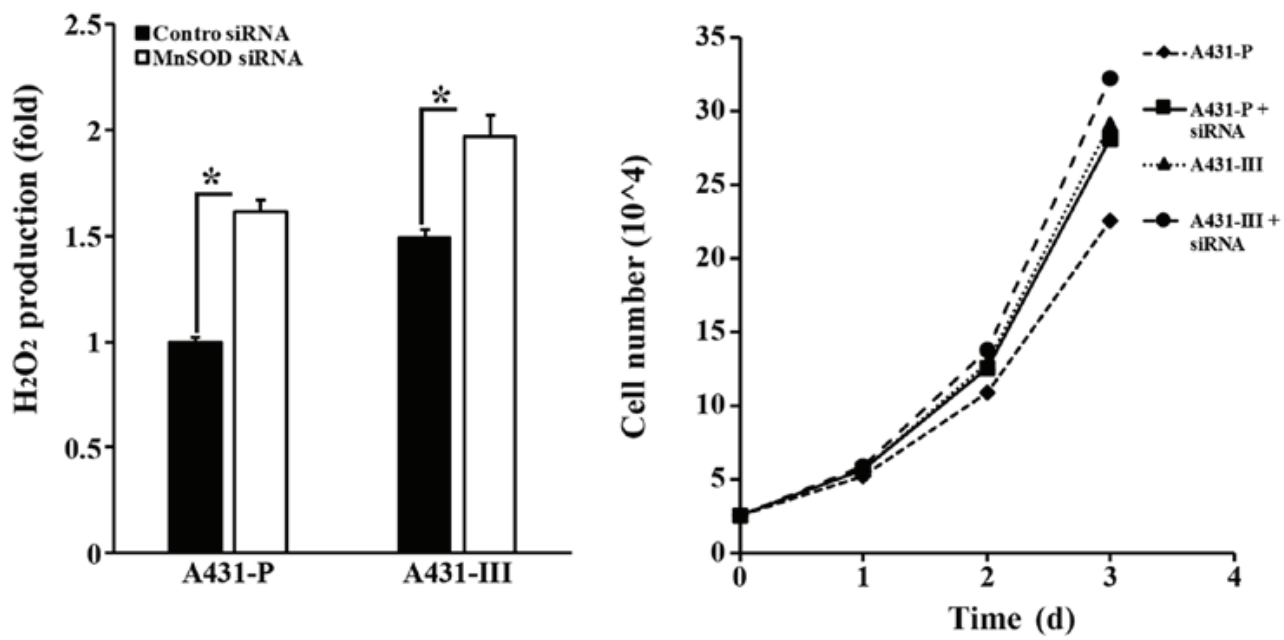

Time (d)

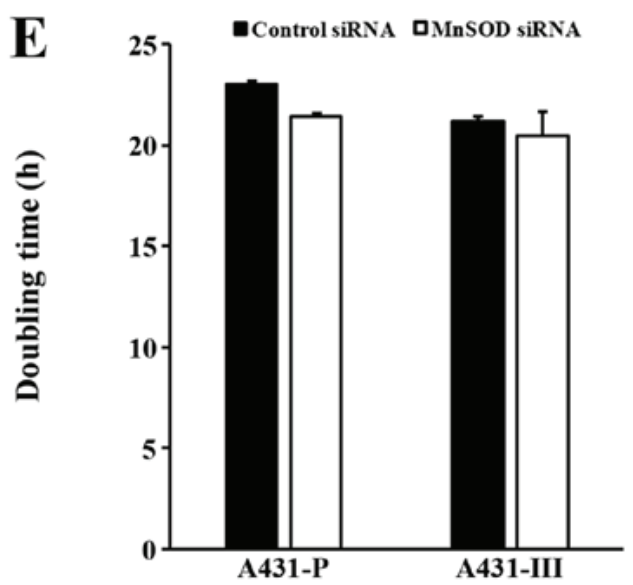

Figure 2. MnSOD knockdown increases the production of $\mathrm{H}_{2} \mathrm{O}_{2}$. (A) Protein levels of MnSOD and CuSOD were determined using western blot analysis following transfection with MnSOD siRNA and control siRNA in A431-P and A431-III cells, respectively. (B) Production of $\mathrm{H}_{2} \mathrm{O}_{2}$ in A431-P and A431-III cells was measured using 2',7'-dichlorofluorescin diacetate incubation followed by fluorescent microscopy (magnification, x200) and (C) detection of the fluorescent intensity using the Amplex ${ }^{\circledR}$ Red Hydrogen Peroxide/Peroxidase Assay kit. (D) Cell growth and (E) doubling times of A431-P and A431-III cells transfected with MnSOD and control siRNA. MnSOD, manganese superoxide dismutase; $\mathrm{H}_{2} \mathrm{O}_{2}$, hydrogen peroxide; CuSOD, copper superoxide dismutase; siRNA, small interfering RNA. Statistical significance was determined by a one-way ANOVA with Tukey's test ( $\left.{ }^{*} \mathrm{P}<0.05\right)$.

catalase levels were lower in the A431-III cells than in the A431-P cells (Fig. 1A). Analysis using the oxidant-sensitive dye 2',7'-DCF-DA revealed that $\mathrm{H}_{2} \mathrm{O}_{2}$ production 15 and $30 \mathrm{~min}$ following dye application was increased 1.7 - and 2.6-fold, respectively, in the A431-III cells compared with that in the A431-P cells (Fig. 1B and C). The enzymatic activity of MnSOD was also higher in the A431-III cells than in the A431-P cells (Fig. 1D). These results suggest that the higher production of $\mathrm{H}_{2} \mathrm{O}_{2}$ in A431-III cells may be regulated by MnSOD and catalase.
Knockdown of the expression of MnSOD enhances the production of $\mathrm{H}_{2} \mathrm{O}_{2}$. To analyze the effect on the production of $\mathrm{H}_{2} \mathrm{O}_{2}$, siRNA knockdown was used to reduce the expression of MnSOD. Western blotting confirmed that the protein level of MnSOD was reduced by the siRNA in the A431-P and A431-III cell lines. The protein level of CuSOD was not altered by the siRNA (Fig. 2A). The knockdown of MnSOD increased the production of $\mathrm{H}_{2} \mathrm{O}_{2}$ by 1.6- and 2.0-fold in the A431-P and A431-III cell lines, respectively, compared with that in the control groups (Fig. 2B and C). The cell numbers and doubling 
A

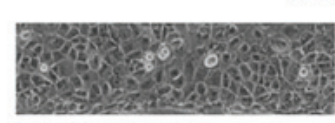

$\mathbf{0 ~ h}$
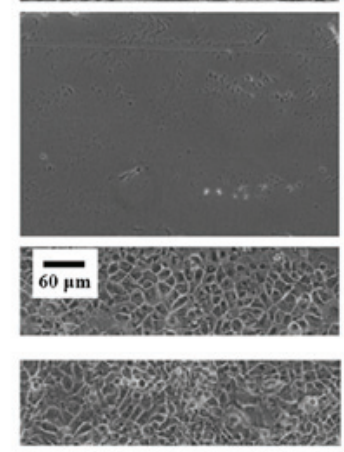

24 h
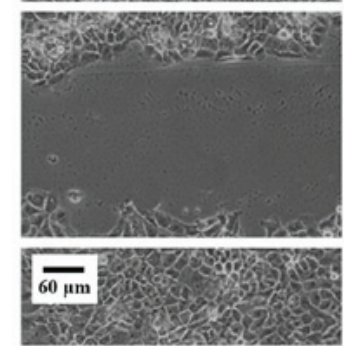

Control

siRNA

B

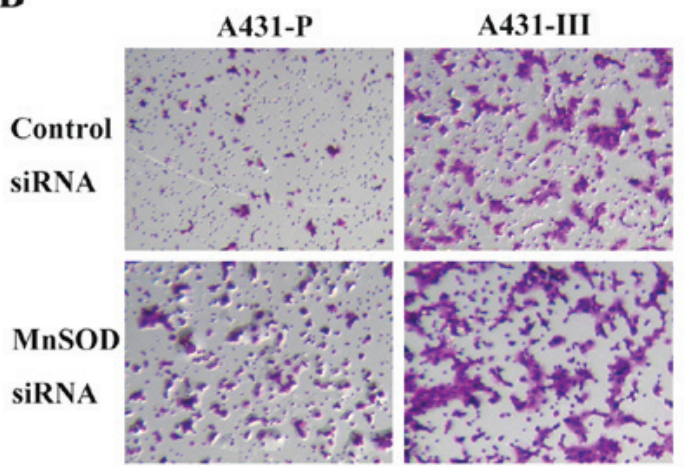

MnSOD

SIRNA

A431-III
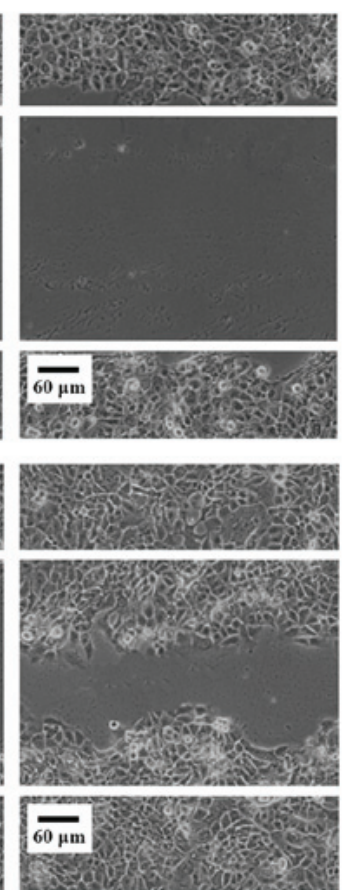

C
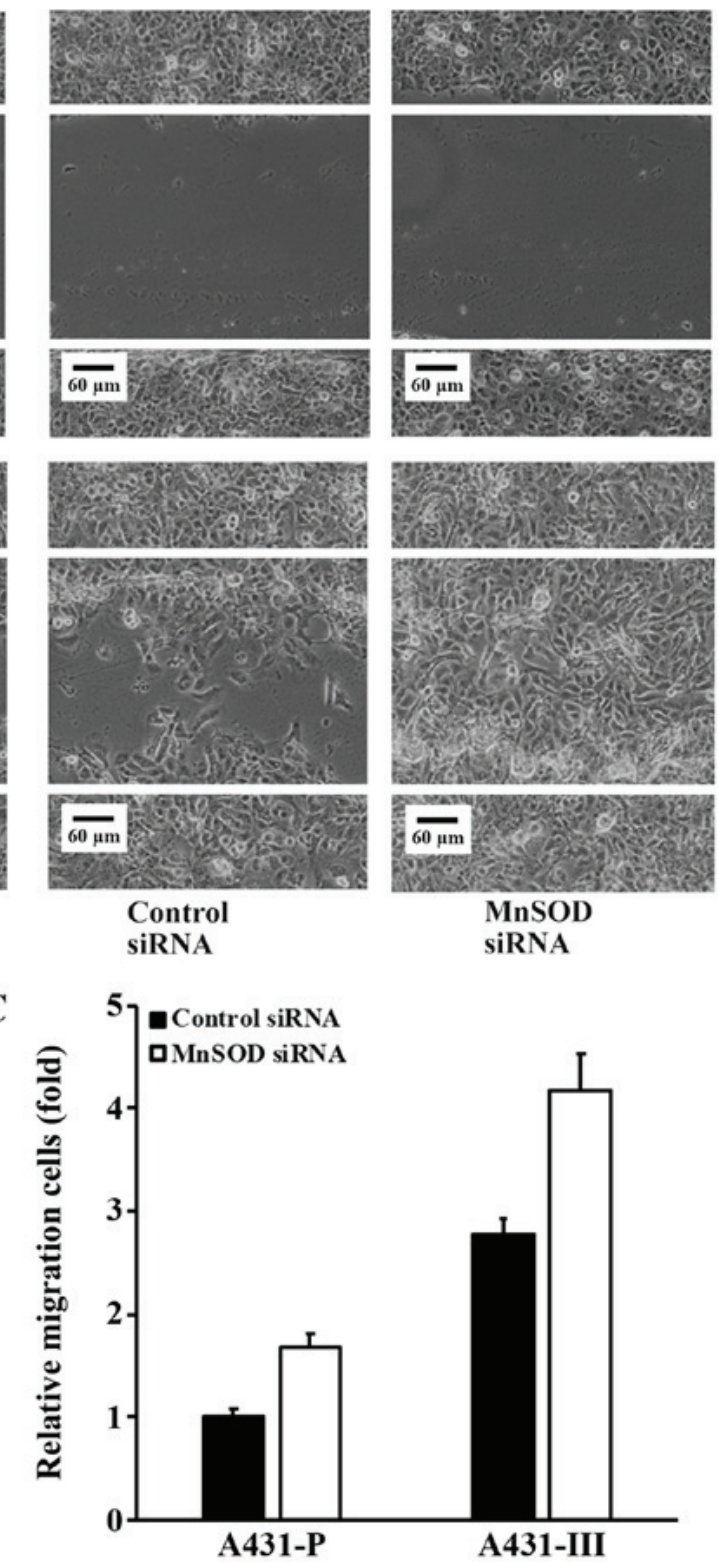

Control
siRNA
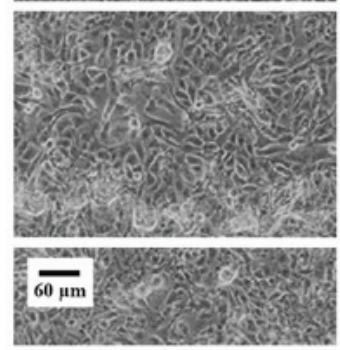

MnSOD
SiRNA

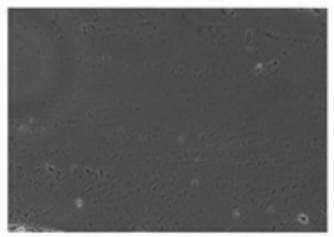

Figure 3. MnSOD knockdown increases the migratory ability of A431-P and A431-III cells. (A) Wound-healing assay and (B) migration assay using A431-P and A431-III cells transfected with MnSOD siRNA and control siRNA (magnification, x200). (C) Quantification of migration ability. MnSOD, manganese superoxide dismutase; siRNA, small interfering RNA.

times of the A431-P and A431-III cells were not significantly affected by the knockdown of MnSOD (Fig. 2D and E). These results suggest that loss of the expression of MnSOD may increase the production of $\mathrm{H}_{2} \mathrm{O}_{2}$.

Knockdown of the expression of MnSOD increases the migratory ability of cancer cells. To analyze the effect of altering the expression of MnSOD on cell migratory ability, wound-healing and cell-migration assays were performed using the A431-P and A431-III cells. The knockdown of MnSOD increased the migratory ability of the A431-P and A431-III cells in the wound-healing experiment (Fig. 3A); migration was increased 1.68-fold in the A431-P cells with MnSOD siRNA knockdown, compared with that of the cells transfected with control siRNA. The migration ability of the A431-III cells increased from 2.77-fold to 4.17-fold by MnSOD siRNA knockdown compared

A431-III 
A
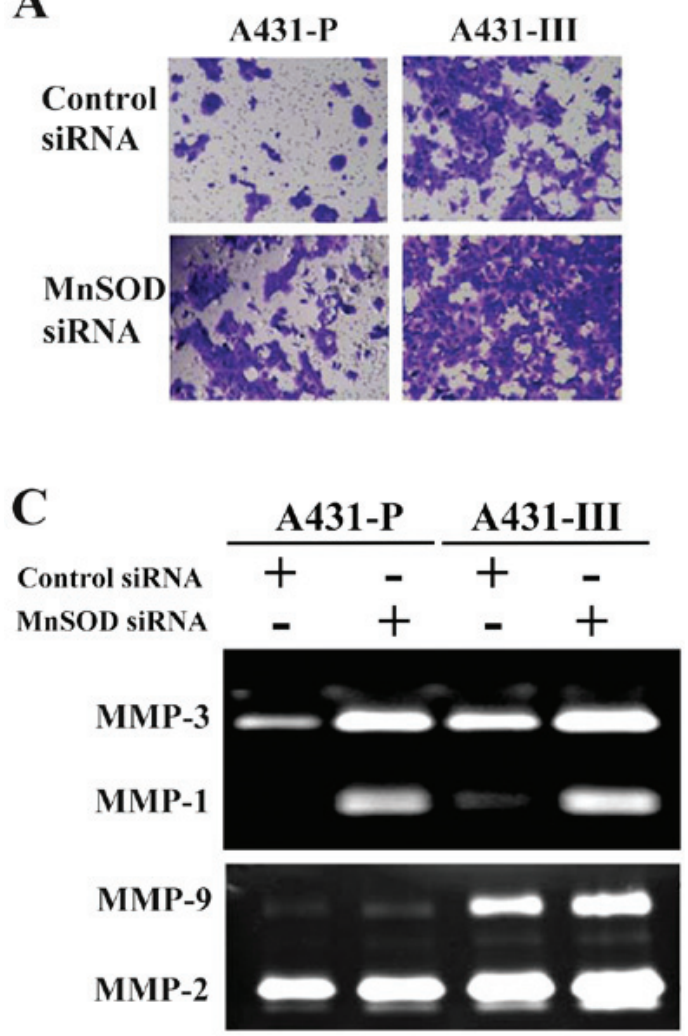

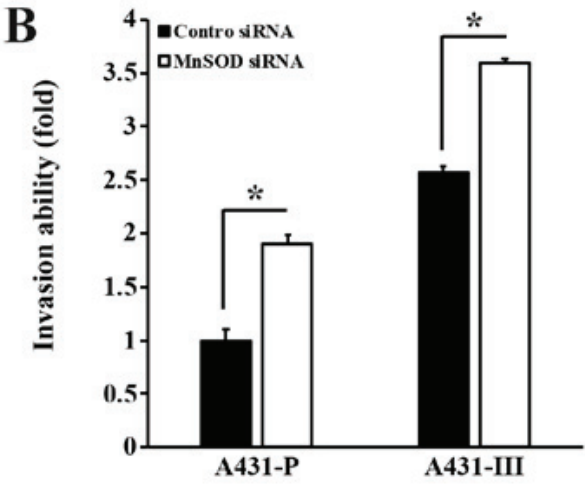

D

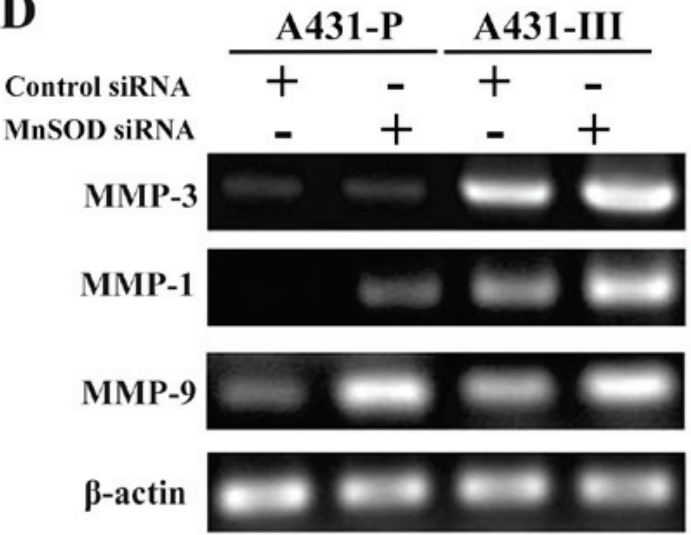

Figure 4. MnSOD knockdown increases the invasive abilities of A431-P and A431-III cells and increases the activity of metalloproteinases. (A) Invasion abilities of A431-P and A431-III cells were examined following transfection with MnSOD siRNA and control siRNA (magnification, $\mathrm{x} 200$ ). (B) Cells that penetrated through the Matrigel to the lower surface of the filters were stained and counted by microscopy. Statistical significance was determined by a one-way ANOVA with Tukey's test ( $\left.{ }^{*} \mathrm{P}<0.05\right)$. (C) Conditioned media of A431-P and A431-III cells transfected with MnSOD siRNA and control siRNA were collected and normalized by cell numbers. Casein and gelatin zymographic assays were used to analyze the enzyme activities of MMP-1, -2 , -3 and -9 . (D) Reverse transcription-polymerase chain reaction was used to analyze the mRNA levels of MMP-1, -3 and -9 following MnSOD siRNA and control siRNA transfection. MnSOD, manganese superoxide dismutase; MMP, matrix metalloproteinase.

the protein activity (Fig. 4C) and mRNA (Fig. 4D) levels of MMP-1, -3 and -9 were increased by MnSOD knockdown. Collectively, these results suggest that the invasive ability of cancer cells was increased by MnSOD siRNA knockdown, which also increased the expression and enzymatic activities of MMP-1, -3 and -9 .

Migratory ability of cancer cells is regulated by $\mathrm{H}_{2} \mathrm{O}_{2}$. In the present study, the knockdown of MnSOD increased the production of $\mathrm{H}_{2} \mathrm{O}_{2}$, and increased the migratory and invasive abilities of cancer cells. To elucidate the roles of $\mathrm{H}_{2} \mathrm{O}_{2}$ in the migratory ability of cancer cells, the oxidant-sensitive dye 2',7'-DCF-DA and wound-healing experiments were performed using A431-III cells. The production of $\mathrm{H}_{2} \mathrm{O}_{2}$ was reduced by treatment with $2.5 \mu \mathrm{M}$ of DPI and $5 \mathrm{mM}$ of NAC (Fig. 5A). To further analyze the effect on the migratory ability of cancer cells by $\mathrm{H}_{2} \mathrm{O}_{2}$ production, wound-healing experiments were performed. The migratory ability of A431-P cells was increased following treatment with $\mathrm{H}_{2} \mathrm{O}_{2}$ in a dose-dependent manner (Fig. 5B); however, the migratory ability of A431-III cells was reduced by DPI (1.5 and $2.5 \mu \mathrm{M})$ and NAC (5 $\mu \mathrm{M}$; Fig. 5C). These data suggest that the migratory ability of cancer cells is regulated by the levels of $\mathrm{H}_{2} \mathrm{O}_{2}$.

DPI reverses the migratory ability induced by MnSOD knockdown. MnSOD siRNA was used to elucidate the role of
$\mathrm{H}_{2} \mathrm{O}_{2}$ in the enhanced migratory ability of cancer cells induced by MnSOD knockdown. MnSOD siRNA increased the production of $\mathrm{H}_{2} \mathrm{O}_{2}$ by 1.46-fold in the A431-P cells compared with cells in the control siRNA group. In the A431-III cells, the production of $\mathrm{H}_{2} \mathrm{O}_{2}$ was increased from 1.3-fold in the control group to 2.1-fold in the MnSOD knockdown cells. The production of $\mathrm{H}_{2} \mathrm{O}_{2}$ increased by MnSOD siRNA was reduced to 0.1 - and 0.21 -fold by $2.5 \mu \mathrm{M}$ of DPI treatment in the A431-P and A431-III cells, respectively (Fig. 6A). The migratory abilities of the A431-P and A431-III cells were increased by MnSOD siRNA, and this effect was abrogated by treatment with $2.5 \mu \mathrm{M}$ of DPI (Fig. 6B). These results suggest that altered MnSOD levels/activity may increase the production of $\mathrm{H}_{2} \mathrm{O}_{2}$, resulting in an increase in the migratory ability of cancer cells.

$\mathrm{Lu}$ and $\mathrm{Qu}$ reduce the production of $\mathrm{H}_{2} \mathrm{O}_{2}$ and increase the expression of catalase. In our previous reports, $\mathrm{Lu}$ and $\mathrm{Qu}$ were demonstrated to inhibit the metastasis of cancer cells (34-37). In the present study, the migratory and invasive abilities of cancer cells were associated with the level of $\mathrm{H}_{2} \mathrm{O}_{2}$. To analyze the effects of $\mathrm{Lu}$ and $\mathrm{Qu}$ on the production of $\mathrm{H}_{2} \mathrm{O}_{2}$, the cells were probed with the oxidant-sensitive dye, 2',7'-DCF-DA, following treatment of the A431-III cells with $\mathrm{Lu}$ and $\mathrm{Qu}$. The $\mathrm{H}_{2} \mathrm{O}_{2}$ level was significantly reduced, by 0.6 - and 0.5 -fold. following treatment with $20 \mu \mathrm{M}$ of $\mathrm{Lu}$ and $\mathrm{Qu}$, respectively, compared with that in the control group (Fig. 7A and B). In 
$\mathbf{A}$

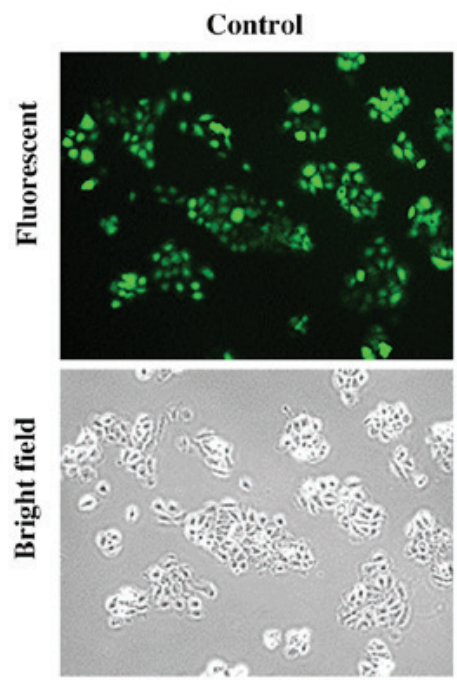

$2.5 \mu \mathrm{M}$ DPI

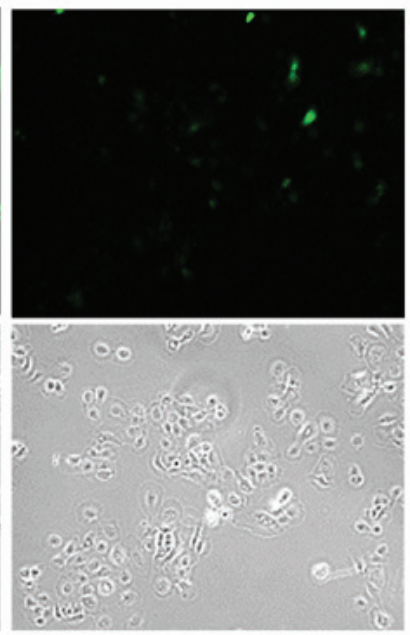

5 mM NAC
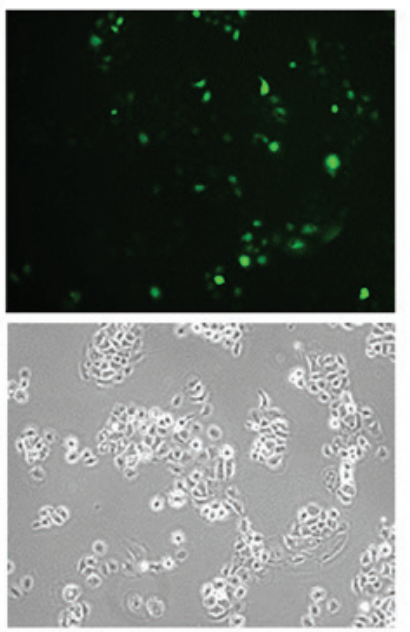

B

A431-P Control

$10 \mu \mathrm{M} \mathrm{H_{2 }} \mathrm{O}_{2}$
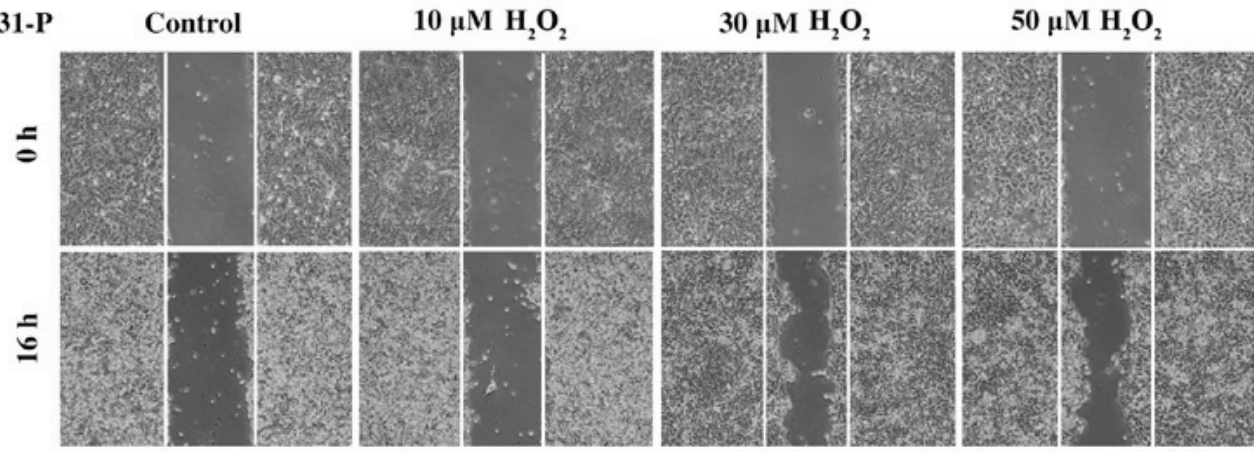

C A431-III

Control

1.5 $\mu \mathrm{M}$ DPI
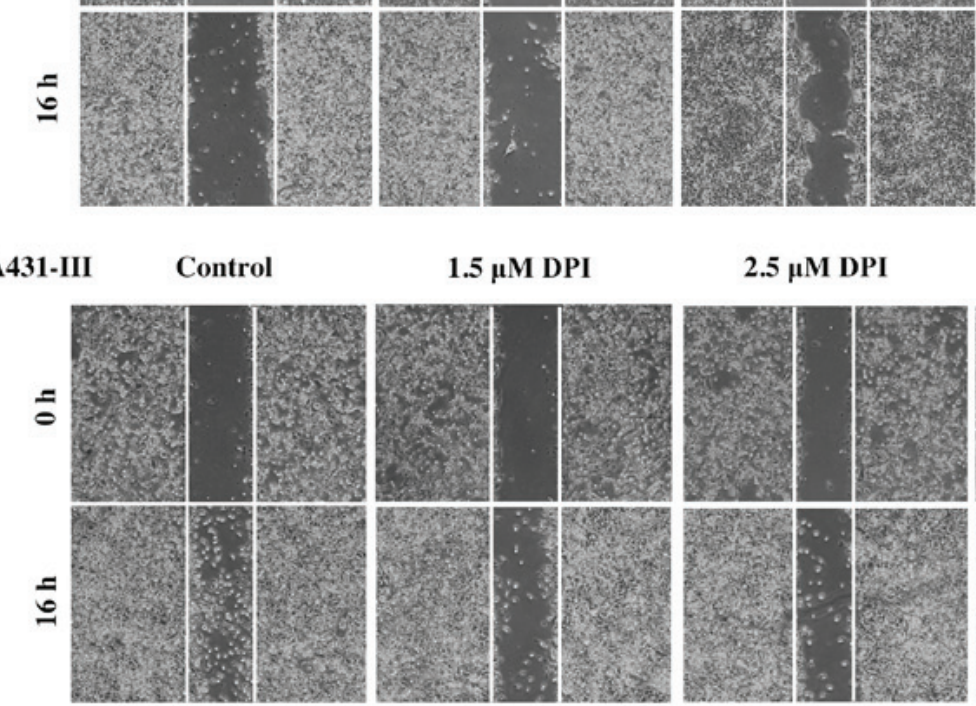

$2.5 \mu \mathrm{M}$ DPI

$5 \mu \mathrm{M}$ NAC
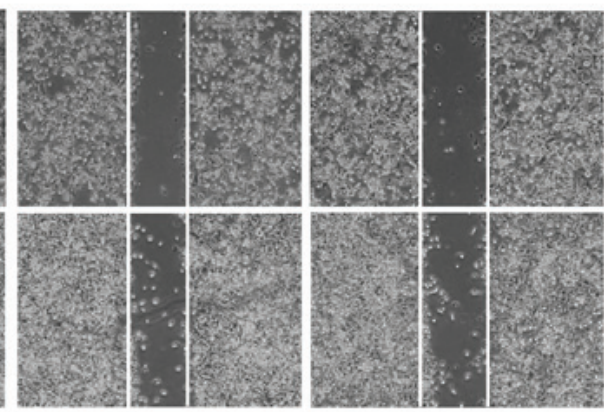

Figure 5. $\mathrm{H}_{2} \mathrm{O}_{2}$ promotes the migratory abilities of A431-P and A431-III cells. (A) $\mathrm{H}_{2} \mathrm{O}_{2}$ in A431-P and A431-III cells following treatment with $2.5 \mu \mathrm{M}$ of DPI and $5 \mathrm{mM}$ of NAC was measured using 2',7'-dichlorofluorescin diacetate and fluorescent microscopy (magnification, x200). (B) A wound-healing assay was used to analyze the migratory ability in A431-P cells following treatment with 10,30 and $50 \mu \mathrm{M}$ of $\mathrm{H}_{2} \mathrm{O}_{2}$ for $16 \mathrm{~h}$ (magnification, x100). (C) A wound-healing assay was used to analyze the migratory ability of A431-III cells following treatment with 1.5 and $2.5 \mu \mathrm{M}$ of DPI and $5 \mu \mathrm{M}$ of NAC for $16 \mathrm{~h}$ (magnification, x100). $\mathrm{H}_{2} \mathrm{O}_{2}$, hydrogen peroxide; DPI, diphenyleneiodonium; NAC, $\mathrm{N}$-acetyl-1-cysteine.

further analysis of the effects of $\mathrm{Lu}$ and $\mathrm{Qu}$ on the expressions of MnSOD and catalase, the protein levels of MnSOD did not alter, however, the levels of catalase were increased (Fig. 7C). These data suggest that $\mathrm{Lu}$ and $\mathrm{Qu}$ reduced $\mathrm{H}_{2} \mathrm{O}_{2}$ levels by increasing the protein level of catalase, without an effect on the level of MnSOD.

\section{Discussion}

Cancer cells exhibit high ROS levels and increased antioxidant capacity (2). In A431-III cells, the high expression of MnSOD and low expression of catalase may increase the antioxidant capacity of cancer cells. The knockdown of MnSOD in
A431-III cells may induce an imbalance of ROS and increase the migratory and invasive ability of cancer cells. In the present study, $\mathrm{Lu}$ and $\mathrm{Qu}$ reduced the production of $\mathrm{H}_{2} \mathrm{O}_{2}$ and increased the expression of catalase (Fig. 7).

ROS are reported to downregulate catalase via the activation of PI3K/Akt signaling to reduce the activity of forkhead box protein O1 (FoxO1) in mesangial cells (41). In our previous reports, Lu and Qu inhibited Akt/mTOR/cMyc signaling to repress RPS19- and RPS12-activated metastasis in A431-III cells $(35,36)$. In the present study, the levels of $\mathrm{H}_{2} \mathrm{O}_{2}$ were higher and catalase levels were lower in A431-III cells than in A431-P cells; the low of catalase in A431-III cells may be caused by the $\mathrm{H}_{2} \mathrm{O}_{2}$-induced activation of Akt/FoxO1 


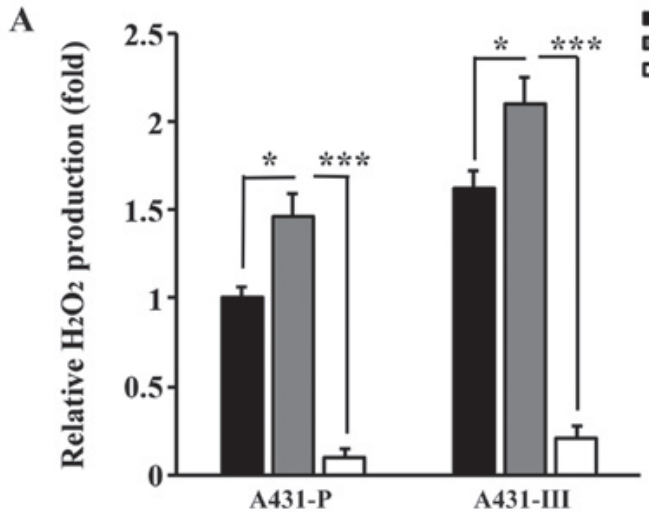

B
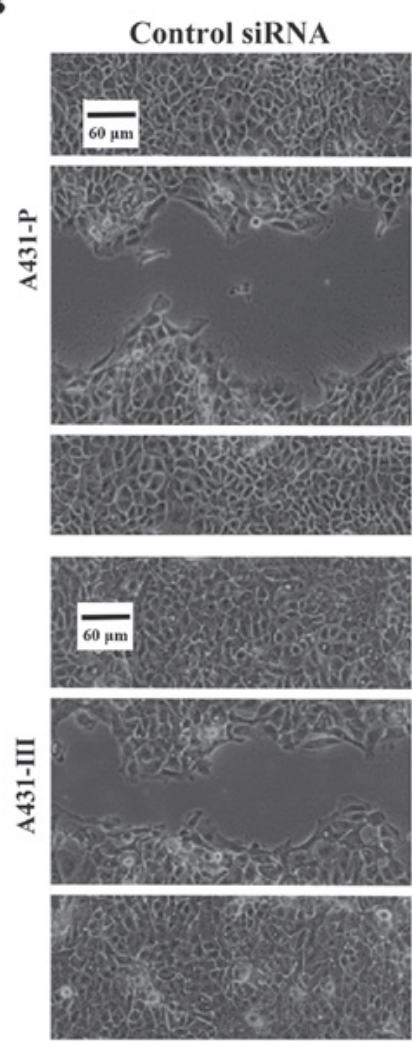
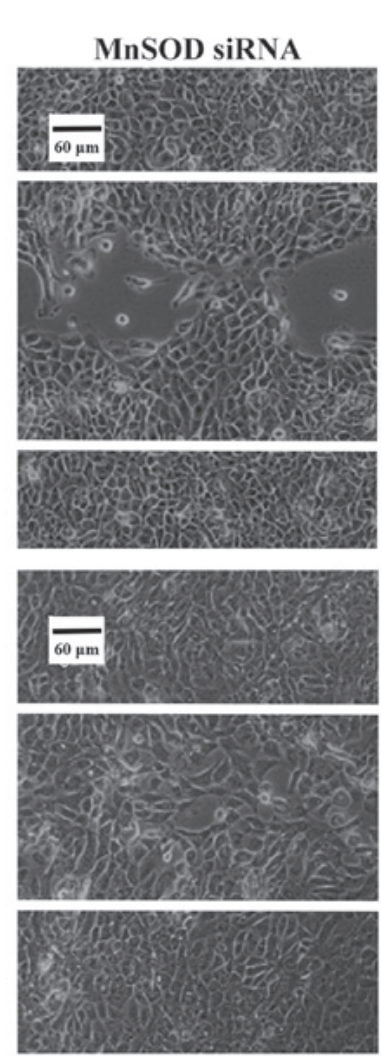

-Control siRNA

MnSDO SiRNA

QMnSOD SIRNA+ DPI
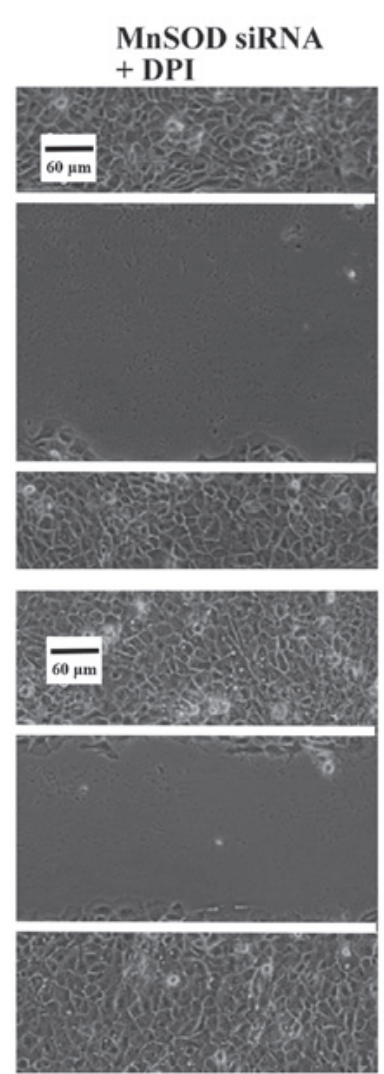

Figure 6. DPI reverses $\mathrm{H}_{2} \mathrm{O}_{2}$ production and the migratory ability induced by MnSOD knockdown in A431-P and A431-III cells. Following transfection of A431-P and A431-III cells with MnSOD siRNA and control siRNA, cells were treated with or without DPI. (A) Production of $\mathrm{H}_{2} \mathrm{O}_{2}$ was measured by 2',7'-dichlorofluorescin diacetate and fluorescence incubation, and the fluorescent intensity was detected using the Amplex ${ }^{\circledR}$ Red Hydrogen Peroxide/Peroxidase Assay kit. Statistical significance was determined by a one-way ANOVA with Tukey's test ( $\left.\mathrm{P}<0.05,{ }^{* * *} \mathrm{P}<0.001\right)$. (B) A wound-healing assay was performed to analyze the migratory abilities of A431-P and A431-III cells transfected with control siRNA, and MnSOD siRNA alone or combined with DPI (magnification, x200). MnSOD, manganese superoxide dismutase; DPI, diphenyleneiodonium; $\mathrm{H}_{2} \mathrm{O}_{2}$, hydrogen peroxide; siRNA, small interfering RNA.

signaling. $\mathrm{Lu}$ and $\mathrm{Qu}$ increased the expression of catalase and reduced the production of $\mathrm{H}_{2} \mathrm{O}_{2}$ in A431-III cells. The inhibition of Akt signaling by $\mathrm{Lu}$ and Qu may activate FoxO1 and, thus increase the expression of catalase $(41,42)$. Further analysis is required to elucidate the mechanism by which $\mathrm{Lu}$ and $\mathrm{Qu}$ increase the expression of catalase.

The knockdown of MnSOD using siRNA reduces the migratory and invasive abilities of cancer cells $(43,44)$; however, in a previous study, the reduced migratory and invasive abilities caused by MnSOD knockdown were restored by the combined knockdown of homeobox protein Nkx2.1 in lung adenocarcinomas (44). Reports have demonstrated that the migratory and invasive abilities of cancer cells are regulated by the expression of MnSOD and other factors in cancer cells $(7,8,43)$. In the present study, the knockdown of MnSOD by siRNA promoted the migratory and invasive abilities of the A431-P and A431-III cells. Notably, the production of $\mathrm{H}_{2} \mathrm{O}_{2}$ was increased by the knockdown of MnSOD. One potential explanation for this is an increase in superoxide efflux from the mitochondria to the cytoplasm and the conversion of superoxide to $\mathrm{H}_{2} \mathrm{O}_{2}$ by CuSOD. Confirmation of this hypothesis requires further analysis.

$\mathrm{Lu}$ and $\mathrm{Qu}$ have been frequently reported as important potential anticancer and antioxidant agents. Lu has been demonstrated to activate catalase in HT-29 cells, $\mathrm{CH} 27$ cells and in a mouse model $(27,45,46)$. Although the expression of MnSOD was increased by Lu in $\mathrm{CH} 27$ cells (27), the same effect was not observed in A431-P or A431-III cells. 


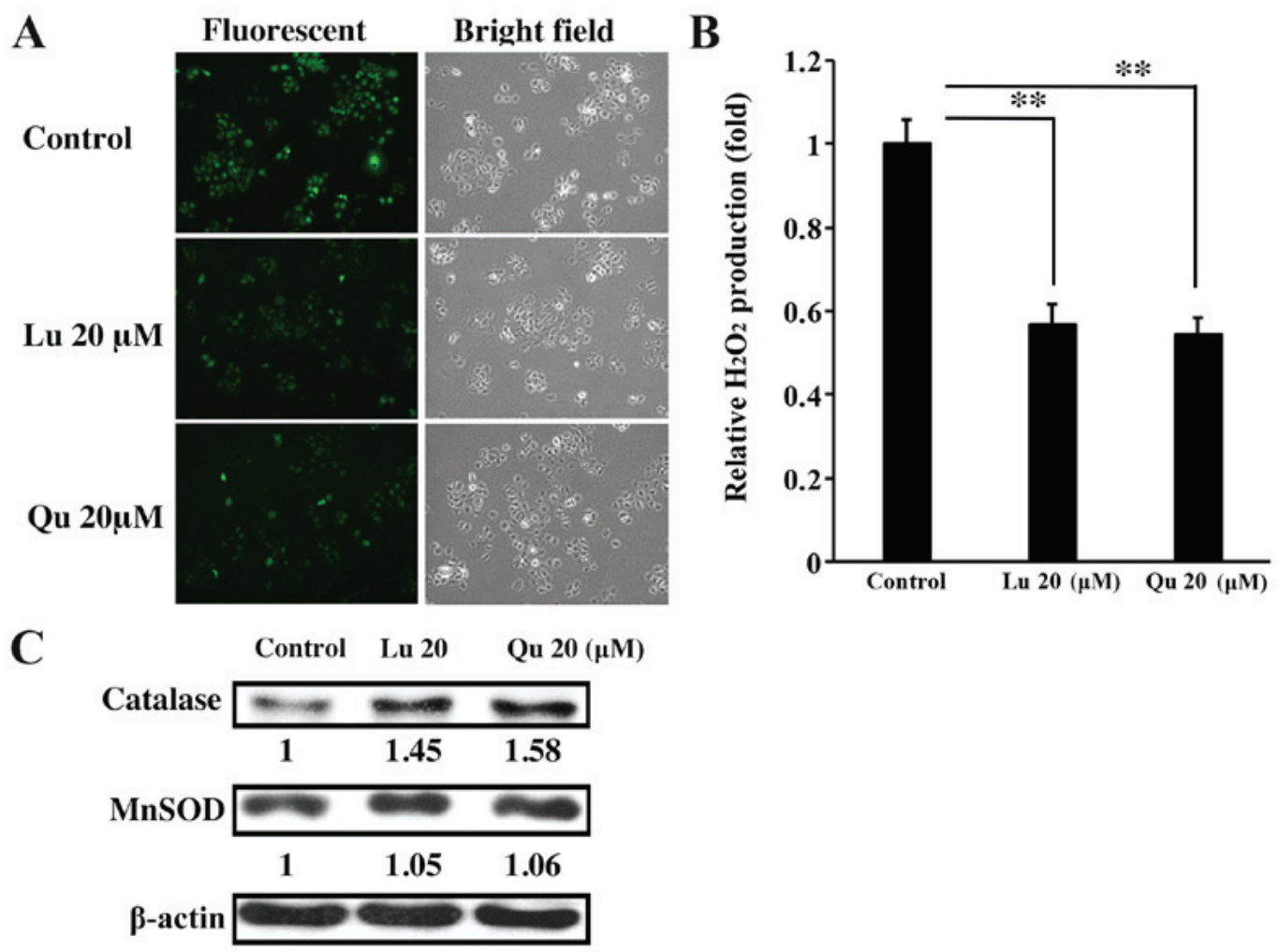

Figure 7. $\mathrm{Lu}$ and $\mathrm{Qu}$ reduce the production of $\mathrm{H}_{2} \mathrm{O}_{2}$ by increasing the expression of catalase. (A) A431-P and A431-III cells were treated with $20 \mu \mathrm{M}$ of $\mathrm{Lu}$ and $\mathrm{Qu}$ for $24 \mathrm{~h}$. The production of $\mathrm{H}_{2} \mathrm{O}_{2}$ in A431-P and A431-III cells was measured by using 2',7'-dichlorofluorescin diacetate and fluorescent microscope (magnification, $\mathrm{x} 200$ ), and (B) fluorescent intensity was detected using the Amplex ${ }^{\circledR}$ Red Hydrogen Peroxide/Peroxidase Assay kit. Statistical significance was determined by a one-way ANOVA with Tukey's test ("* $\mathrm{P}<0.01)$. (C) Protein levels of catalase and MnSOD were determined using western blot analysis. $\mathrm{Lu}$, luteolin; $\mathrm{Qu}$, quercetin; $\mathrm{H}_{2} \mathrm{O}_{2}$, hydrogen peroxide; $\mathrm{MnSOD}$, manganese superoxide dismutase.
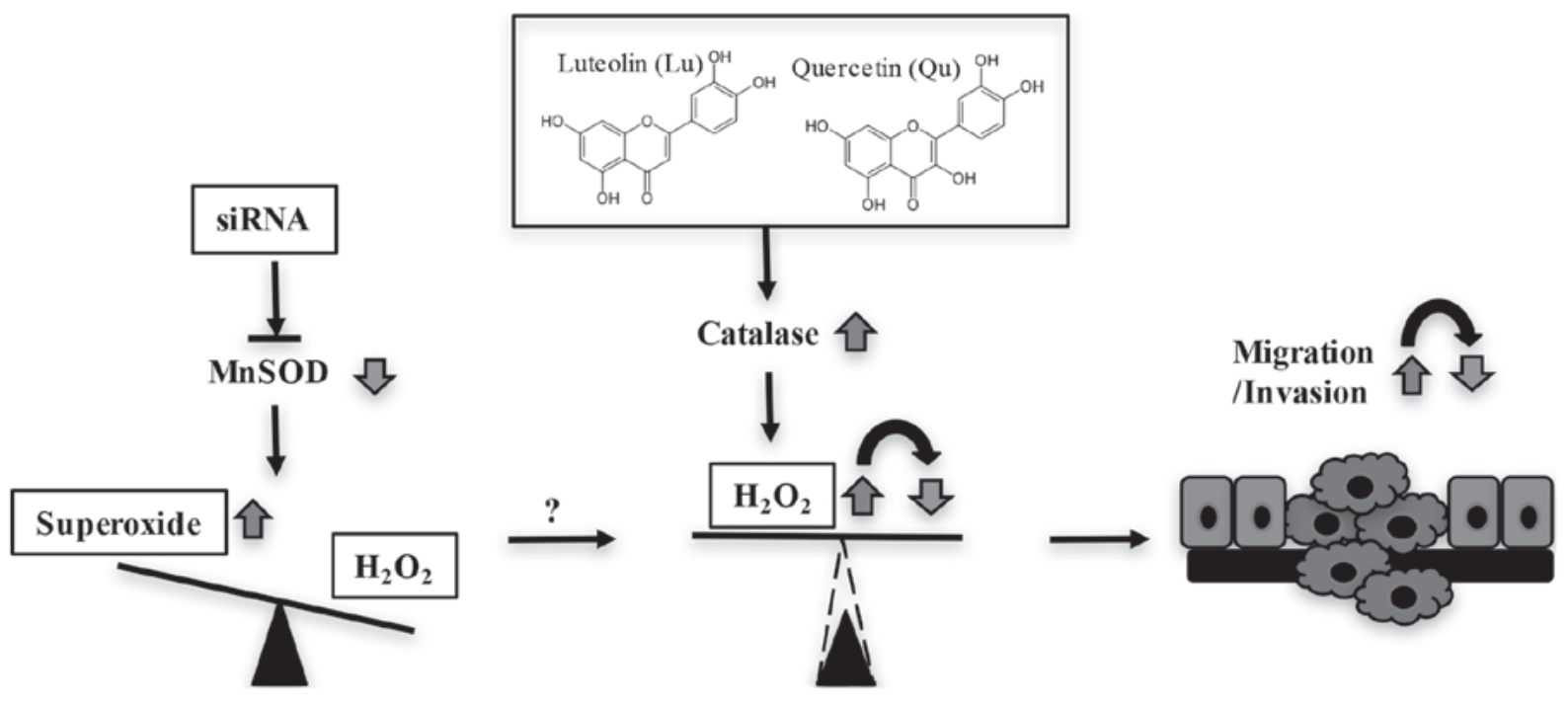

Figure 8. Schematic of the ROS imbalance induced by a reduction in MnSOD. A reduction in MnSOD increases the production of $\mathrm{H}_{2} \mathrm{O}_{2}$, which is induced by an unknown signaling mechanism. Luteolin and quercetin treatment increased the expression of catalase and reduce the production of $\mathrm{H}_{2} \mathrm{O}_{2}$. Subsequently, the migration and invasive ability of the invasive A431-III cells is reduced. ROS, reactive oxygen species; MnSOD, manganese superoxide dismutase; $\mathrm{H}_{2} \mathrm{O}_{2}$, hydrogen peroxide; siRNA, small interfering RNA.

$\mathrm{Qu}$ has been reported to restore the activity of catalase in a Huntington's disease mouse model (29), a diabetic rat model (47), in spermatozoa (48) and for neuroprotection in rat brains (49). These reports are consistent with the finding of the present study, whereby the expression of catalase was induced by $\mathrm{Lu}$ and $\mathrm{Qu}$.
The data obtained in the present study indicate that the imbalance of ROS in A431-P and A431-III cells is due to reduced MnSOD activity, which subsequently promotes the metastatic ability of cancer cells. MnSOD may not be a suitable therapeutic target in squamous cell carcinoma; however, using antioxidant agents, such as $\mathrm{Lu}$ and $\mathrm{Qu}$, to reduce $\mathrm{H}_{2} \mathrm{O}_{2}$ 
by increasing catalase activity, may be a useful therapeutic strategy (Fig. 8).

\section{Acknowledgements}

Not applicable.

\section{Funding}

This study was supported by Taipei Medical University-Wan Fang Hospital (grant no. 105TMU-WFH-14, 2016) and the Ministry of Science and Technology, Taiwan (grant no. MOST1072320-B-038-036, 2018).

\section{Availability of data and materials}

The data and materials used in the present study are available from the corresponding author on reasonable request.

\section{Authors' contributions}

WHH, MTL, CWL and CHC conceived and designed the study. JJF, HHH and WJZ performed the majority of the experiments and analyzed the data. TPK and YLAL assisted with manuscript preparation and data analysis. KCC assisted with RT-PCR analysis. CYC assisted with western blotting. All authors have read and approved the final manuscript.

\section{Ethics approval and consent to participate}

Not applicable.

\section{Patient consent for publication}

Not applicable.

\section{Competing interests}

The authors declare that they have no competing interests.

\section{References}

1. Aon MA, Cortassa S and O'Rourke B: Redox-optimized ROS balance: A unifying hypothesis. Biochim Biophys Acta 1797: 865-877, 2010

2. Panieri E and Santoro MM: ROS homeostasis and metabolism: A dangerous liason in cancer cells. Cell Death Dis 7: e2253-e2253, 2016.

3. Kim YS, Gupta Vallur P, Phaëton R, Mythreye K and Hempel N: Insights into the dichotomous regulation of SOD2 in cancer. Antioxidants 6: 86, 2017.

4. Weydert C, Roling B, Liu J, Hinkhouse MM, Ritchie JM, Oberley LW and Cullen JJ: Suppression of the malignant phenotype in human pancreatic cancer cells by the overexpression of manganese superoxide dismutase. Mol Cancer Ther 2: 361-369, 2003.

5. Zhong W, Oberley LW, Oberley TD and St Clair DK: Suppression of the malignant phenotype of human glioma cells by overexpression of manganese superoxide dismutase. Oncogene 14: 481-490, 1997.

6. Nelson KK, Ranganathan AC, Mansouri J, Rodriguez AM, Providence KM, Rutter JL, Pumiglia K, Bennett JA and Melendez JA: Elevated sod2 activity augments matrix metalloproteinase expression: Evidence for the involvement of endogenous hydrogen peroxide in regulating metastasis. Clin Cancer Res 9: 424-432, 2003.
7. Connor KM, Hempel N, Nelson KK, Dabiri G, Gamarra A, Belarmino J, Van De Water L, Mian BM and Melendez JA: Manganese superoxide dismutase enhances the invasive and migratory activity of tumor cells. Cancer Res 67: 10260-10267, 2007.

8. Chen PM, Wu TC, Shieh SH, Wu YH, Li MC, Sheu GT, Cheng YW, Chen CY and Lee H: MnSOD promotes tumor invasion via upregulation of FoxM1-MMP2 axis and related with poor survival and relapse in lung adenocarcinomas. Mol Cancer Res 11: 261-271, 2013.

9. Malafa M, Margenthaler J, Webb B, Neitzel L and Christophersen M: MnSOD expression is increased in metastatic gastric cancer. J Surg Res 88: 130-134, 2000

10. Li S, Mao Y, Zhou T, Luo C, Xie J, Qi W, Yang Z, Ma J, Gao G and Yang $\mathrm{X}$ : Manganese superoxide dismutase mediates anoikis resistance and tumor metastasis in nasopharyngeal carcinoma. Oncotarget 7: 32408-32420, 2016.

11. Miar A, Hevia D, Muñoz-Cimadevilla H, Astudillo A, Velasco J, Sainz RM and Mayo JC: Manganese superoxide dismutase (SOD2/MnSOD)/catalase and SOD2/GPx1 ratios as biomarkers for tumor progression and metastasis in prostate, colon, and lung cancer. Free Radic Biol Med 85: 45-55, 2015.

12. Porporato PE, Payen VL, Pérez-Escuredo J, De Saedeleer CJ, Danhier P, Copetti T, Dhup S, Tardy M, Vazeille T, Bouzin C, et al: A mitochondrial switch promotes tumor metastasis. Cell Rep 8: 754-766, 2014.

13. Porporato PE and Sonveaux P: Paving the way for therapeutic prevention of tumor metastasis with agents targeting mitochondrial superoxide. Mol Cell Oncol 2: e968043, 2014.

14. Heim KE, Tagliaferro AR and Bobilya DJ: Flavonoid antioxidants: Chemistry, metabolism and structure-activity relationships. J Nutr Biochem 13: 572-584, 2002.

15. Pietta PG: Flavonoids as antioxidants. J Nat Prod 63: 1035-1042, 2000.

16. Nijveldt RJ, van Nood E, van Hoorn DE, Boelens PG, van Norren K and van Leeuwen PAM: Flavonoids: A review of probable mechanisms of action and potential applications. Am J Clin Nutr 74: 418-425, 2001.

17. Procházková $\mathrm{D}$, Boušová I and Wilhelmová N: Antioxidant and prooxidant properties of flavonoids. Fitoterapia 82: 513-523, 2011.

18. Kandaswami C, Lee LT, Lee PP, Hwang JJ, Ke FC, Huang YT and Lee MT: The antitumor activities of flavonoids. In Vivo 19: 895-909, 2005

19. Andarwulan N, Batari R, Sandrasari DA, Bolling B and Wijaya H: Flavonoid content and antioxidant activity of vegetables from Indonesia. Food Chem 121: 1231-1235, 2010.

20. Cao J, Chen W, Zhang Y, Zhang Y and Zhao X: Content of selected flavonoids in 100 edible vegetables and fruits. Food Sci Technol Res 16: 395-402, 2010.

21. Huang YT, Hwang JJ, Lee PP, Ke FC, Huang JH, Huang CJ, Kandaswami C, Middleton E Jr and Lee MT: Effects of luteolin and quercetin, inhibitors of tyrosine kinase, on cell growth and metastasis-associated properties in A431 cells overexpressing epidermal growth factor receptor. Br J Pharmacol 128: 999-1010, 1999.

22. Lee LT, Huang YT, Hwang JJ, Lee PP, Ke FC, Nair MP, Kanadaswam C and Lee MT: Blockade of the epidermal growth factor receptor tyrosine kinase activity by quercetin and luteolin leads to growth inhibition and apoptosis of pancreatic tumor cells. Anticancer Res 22: 1615-1627, 2002.

23. Fotsis T, Pepper MS, Aktas E, Breit S, Rasku S, Adlercreutz H, Wähälä K, Montesano R and Schweigerer L: Flavonoids, dietary-derived inhibitors of cell proliferation and in vitro angiogenesis. Cancer Res 57: 2916-2921, 1997.

24. Kawaii S, Tomono Y, Katase E, Ogawa K and Yano M: Antiproliferative activity of flavonoids on several cancer cell lines. Biosci Biotechnol Biochem 63: 896-899, 1999.

25. Cherng JM, Shieh DE, Chiang W, Chang MY and Chiang LC: Chemopreventive effects of minor dietary constituents in common foods on human cancer cells. Biosci Biotechnol Biochem 71: 1500-1504, 2007.

26. Takahashi T, Kobori M, Shinmoto $H$ and Tsushida T: Structure-activity relationships of flavonoids and the induction of granulocytic- or monocytic-differentiation in HL60 human myeloid leukemia cells. Biosci Biotechnol Biochem 62: 2199-2204, 1998.

27. Leung HW, Kuo CL, Yang WH, Lin CH and Lee HZ: Antioxidant enzymes activity involvement in luteolin-induced human lung squamous carcinoma CH27 cell apoptosis. Eur J Pharmacol 534: $12-18,2006$. 
28. Kang KP, Park SK, Kim DH, Sung MJ, Jung YJ, Lee AS, Lee JE, Ramkumar KM, Lee S, Park MH, et al: Luteolin ameliorates cisplatin-induced acute kidney injury in mice by regulation of p53-dependent renal tubular apoptosis. Nephrol Dial Transplant 26: 814-822, 2011.

29. Sandhir R and Mehrotra A: Quercetin supplementation is effective in improving mitochondrial dysfunctions induced by 3-nitropropionic acid: Implications in Huntington's disease. Biochim Biophys Acta 1832: 421-430, 2013.

30. Mediratta PK, Banerjee BD, HalderS, Kar R and Bhattacharya SK: Effect of chromium on glutathione-S-transferase and catalase activity and their respective gene expressions in the brain tissue of F1 generation mice following prenatal exposure: Modulation by quercetin. J Clin Toxicol 7: 365, 2017.

31. Kao WT, Lin CY, Lee LT, Lee PP, Hung CC, Lin YS, Chen SH, Ke FC, Hwang JJ and Lee MT: Investigation of MMP-2 and -9 in a highly invasive A431 tumor cell sub-line selected from a Boyden chamber assay. Anticancer Res 28: 2109-2120, 2008.

32. Lin CY, Tsai PH, Kandaswami CC, Lee PP, Huang CJ, Hwang JJ and Lee MT: Matrix metalloproteinase- 9 cooperates with transcription factor Snail to induce epithelial-mesenchymal transition. Cancer Sci 102: 815-827, 2011.

33. Lin CY, Tsai PH, Kandaswami CC, Chang GD, Cheng CH, Huang CJ, Lee PP, Hwang JJ and Lee MT: Role of tissue transglutaminase 2 in the acquisition of a mesenchymal-like phenotype in highly invasive A431 tumor cells. Mol Cancer 10: 87, 2011.

34. Lin YS, Tsai PH, Kandaswami CC, Cheng CH, Ke FC, Lee PP, Hwang JJ and Lee MT: Effects of dietary flavonoids, luteolin, and quercetin on the reversal of epithelial-mesenchymal transition in A431 epidermal cancer cells. Cancer Sci 102: 1829-1839, 2011.

35. Chen KC, Hsu WH, Ho JY, Lin CW, Chu CY, Kandaswami CC, Lee MT and Cheng $\mathrm{CH}$ : Flavonoids luteolin and quercetin inhibit RPS19 and contributes to metastasis of cancer cells through c-Myc reduction. J Food Drug Anal 26: 1180-1191, 2018.

36. Lin CW, Lai GM, Chen KC, Lin TH, Fan JJ, Hsu RL, Chou CM, Lin CM, Kandaswami CC, Lee MT, et al: RPS12 increases the invasiveness in cervical cancer activated by c-Myc and inhibited by the dietary flavonoids luteolin and quercetin. J Funct Foods 19: 236-247, 2015

37. Lin TH, Hsu WH, Tsai PH, Huang YT, Lin CW, Chen KC, Tsai IH, Kandaswami CC, Huang CJ, Chang GD, et al: Dietary flavonoids, luteolin and quercetin, inhibit invasion of cervical cancer by reduction of UBE2S through epithelial-mesenchymal transition signaling. Food Funct 8: 1558-1568, 2017.

38. Beauchamp $\mathrm{C}$ and Fridovich I: Superoxide dismutase: Improved assays and an assay applicable to acrylamide gels. Anal Biochem 44: 276-287, 1971.
39. Chin JR, Murphy G and Werb Z: Stromelysin, a connective tissue-degrading metalloendopeptidase secreted by stimulated rabbit synovial fibroblasts in parallel with collagenase. Biosynthesis, isolation, characterization, and substrates. J Biol Chem 260: 12367-12376, 1985.

40. Nishikawa M: Reactive oxygen species in tumor metastasis. Cancer Lett 266: 53-59, 2008.

41. Venkatesan B, Mahimainathan L, Das F, Ghosh-Choudhury N and Ghosh Choudhury G: Downregulation of catalase by reactive oxygen species via PI 3 kinase/Akt signaling in mesangial cells. J Cell Physiol 211: 457-467, 2007.

42. Shen Y, Xu W, You H, Su D, Xing J, Li M, Li L and Liang X: FoxO1 inhibits transcription and membrane trafficking of epithelial $\mathrm{Na}^{+}$ channel. J Cell Sci 128: 3621-3630, 2015

43. Chang B, Yang H, Jiao Y, Wang K, Liu Z, Wu P, Li S and Wang A: SOD2 deregulation enhances migration, invasion and has poor prognosis in salivary adenoid cystic carcinoma. Sci Rep 6: 25918, 2016.

44. Chen PM, Wu TC, Wang YC, Cheng YW, Sheu GT, Chen CY and Lee $\mathrm{H}$ : Activation of NF- $\kappa$ B by SOD2 promotes the aggressiveness of lung adenocarcinoma by modulating NKX2-1-mediated IKK $\beta$ expression. Carcinogenesis 34: 2655-2663, 2013.

45. Kang KA, Piao MJ, Ryu YS, Hyun YJ, Park JE, Shilnikova K, Zhen AX, Kang HK, Koh YS, Jeong YJ, et al: Luteolin induces apoptotic cell death via antioxidant activity in human colon cancer cells. Int J Oncol 51: 1169-1178, 2017.

46. Li Y, Shen L and Luo H: Luteolin ameliorates dextran sulfate sodium-induced colitis in mice possibly through activation of the Nrf2 signaling pathway. Int Immunopharmacol 40: 24-31, 2016.

47. Dias AS, Porawski M, Alonso M, Marroni N, Collado PS and González-Gallego J: Quercetin decreases oxidative stress, NF- $\kappa \mathrm{B}$ activation, and iNOS overexpression in liver of streptozotocin-induced diabetic rats. J Nutr 135: 2299-2304, 2005.

48. Ben Abdallah F, Zribi N and Ammar-Keskes L: Antioxidative potential of Quercetin against hydrogen peroxide induced oxidative stress in spermatozoa in vitro. Andrologia 43: 261-265, 2011.

49. Nabavi SF, Nabavi SM, Latifi AM, Mirzaei M, Habtemariam S and Moghaddam AH: Mitigating role of quercetin against sodium fluoride-induced oxidative stress in the rat brain. Pharm Biol 50: 1380-1383, 2012.

This work is licensed under a Creative Commons Attribution-NonCommercial-NoDerivatives 4.0 International (CC BY-NC-ND 4.0) License. 